\title{
Discours
}

Revue de linguistique, psycholinguistique et informatique. A journal of linguistics, psycholinguistics and computational linguistics

$25 \mid 2019$

Varia

\section{Contrastive Markers in Contrast}

Maria Josep Cuenca, Sorina Postolea and Jacqueline Visconti

\section{OpenEdition}

\section{Journals}

Electronic version

URL: http://journals.openedition.org/discours/10326

DOI: 10.4000/discours. 10326

ISSN: 1963-1723

Publisher:

Laboratoire LATTICE, Presses universitaires de Caen

Electronic reference

Maria Josep Cuenca, Sorina Postolea and Jacqueline Visconti, «Contrastive Markers in Contrast », Discours [Online], 25 | 2019, Online since 30 December 2019, connection on 04 April 2020. URL : http:// journals.openedition.org/discours/10326; DOI : https://doi.org/10.4000/discours.10326 

Revue de linguistique, psycholinguistique et informatique

\title{
Contrastive Markers in Contrast
}

\author{
Maria Josep Cuenca \\ Universitat de València \\ Sorina Postolea \\ Alexandru loan Cuza University of lași \\ Jacqueline Visconti \\ Università di Genova \\ University of Birmingham
}

Maria Josep Cuenca, Sorina Postolea, Jacqueline Visconti, «Contrastive Markers in Contrast», Discours [En ligne], 25 | 2019, mis en ligne le 30 décembre 2019.

URL: http://journals.openedition.org/discours/10326

Titre du numéro: Varia

Coordination: Laure Sarda \& Denis Vigier

Date de réception de l'article: 13/06/2019

Date d'acceptation de l'article: 02/12/2019 



\title{
Contrastive Markers in Contrast
}

\author{
Maria Josep Cuenca
}

Universitat de València

\section{Sorina Postolea}

Alexandru loan Cuza University of lași

\author{
Jacqueline Visconti \\ Università di Genova \\ University of Birmingham
}

Contrastive markers are one of the richest groups of discourse markers in Romance languages. There are several conjunctions and other connectives that can express various types of contrast both at the text level and at the sentence level. In this paper, the main contrastive markers of Spanish, Catalan, Italian and Romanian will be classified and compared as for form, lexical base (or source) and meaning, with the aim of providing a cross-linguistic description of the way in which this class of discourse relations is signaled in these four different Romance languages. Two general meanings will be considered, namely, non-exclusive contrast (including weak contrast, opposition, concessive opposition, and conditional opposition) and exclusive contrast. Our analysis reveals similarities across languages, which go back to common origins, as well as important differences, derived from the fact that each language has developed a paradigmatic system that shows interesting divergences in use.

Keywords: contrast discourse markers, adversativity, contrastive connectives, cross-linguistic analysis, Romance languages, Spanish, Catalan, Italian, Romanian

Les marqueurs discursifs contrastifs constituent l'une des classes de connecteurs discursifs les plus riches dans les langues romanes. Il y a plusieurs conjonctions et d'autres connecteurs qui peuvent exprimer le contraste, à la fois au niveau textuel et au niveau de la phrase. Dans cet article, les marqueurs contrastifs les plus importants de l'espagnol, du catalan, de l'italien et du roumain seront classifiés et comparés en ce qui concerne leur forme, leur base lexicale (ou source) et leur signification. Le but est d'offrir une description interlinguistique de la façon dont cette classe de relations discursives est signalée dans les quatre langues romanes en question. L'article prend en considération deux significations générales, à savoir le contraste non exclusif (comprenant plusieurs types: le contraste faible et l'opposition, l'opposition concessive et l'opposition conditionnelle) et le contraste exclusif. Notre analyse révèle des similarités au niveau de ces langues, liées à leurs origines communes, mais aussi des différences importantes, dues au fait que chacune a développé un système paradigmatique qui produit des disparités intéressantes à l'usage.

Mots clés: marqueurs discursifs de contraste, adversatifs, connecteurs contrastifs, analyse interlinguistique, langues romanes, espagnol, catalan, italien, roumain

This article is the result of a collaborative work carried out by the authors within the COST (European Cooperation in Science and Technology) Action TextLink: "Structuring Discourse in Multilingual Europe (IS1312)". We would like to thank the two anonymous referees for their helpful comments. 


\section{Introduction}

Contrast is a negative coherence relation involving the comparison of two discourse segments. It is one of the basic relations expressed by discourse markers. At the sentence level, contrast is identified with adversativity (roughly corresponding to the meaning of "but"), one of the three types of coordination, along with conjunction (corresponding to the meaning of "and") and disjunction (corresponding to the meaning of "or") (Mauri, 2008: 44). Adversativity differs from both conjunction and disjunction because the latter are serial relations (i.e., can include two or more conjuncts), whereas adversativity is a binary relationship ${ }^{1}$.

However, contrast cannot be limited to adversative compound sentences including a conjunction equivalent to but. It can be expressed by other markers and it can relate independent sentences or groups of sentences. Contrast can be made explicit by markers which according to Cuenca (2001, 2002, 2006 and 2013) can be labeled as parenthetical connectives. Contrastive parenthetical connectives are markers such as however, still, nevertheless, instead, on the contrary or otherwise that can act on their own or following a conjunction (e.g. but or and) linking two segments of discourse (either sentence constituents or independent utterances) that are presented in an antonymic relation.

In this paper, the main contrastive markers in Spanish, Catalan, Italian and Romanian are classified, exemplified and compared as for form, source and meaning. We take as a starting point the classification of markers included in Cuenca (2001) for Spanish and Cuenca (2002 and 2006) for Catalan, which is based on corpus examples. In the case of Spanish, contrastive discourse markers can also be found in DPDE, Fuentes Rodríguez (2009), Martín Zorraquino and Portolés (1999), Portolés (1998) and Santos Río (2003). The classification of Spanish and Catalan contrastive markers is applied to Italian and to Romanian taking into account previous work in these languages. For Italian, contrastive markers are described, among others, in Serianni (1988), Scorretti (1988), and also Mazzoleni (2000), who focuses on contrastive markers in several European languages. Finally, GALR I, GALR II, Ștefănescu (2007), and Zafiu (2005) include descriptions of Romanian adversative discourse markers ${ }^{2}$.

The approach of this analysis is onomasiological and takes into account morphosyntactic as well as semantic and pragmatic distinctive features. The paper is organized as follows. We first identify the different types of contrastive relations (Section 2), which can be grouped together into two broad meanings, namely, non-exclusive contrast and exclusive contrast. Second, the conjunctions expressing

1. Concession is also a contrastive coherence relation, as recognized, for example, in Sanders et al. (2018), who differentiate three types of negative relations, namely, contrast (while), adversative (but), and concession (although) relations. In this paper the focus is on "adversative contrast", that is, additive negative relations.

2. The complete references of the dictionaries are available at the end of this paper. 
contrast in the four languages considered are described (Section 3). Third, the markers, both conjunctions and parenthetical connectives, are grouped according to specific meanings: weak contrast, opposition, concessive opposition and conditional opposition, as for non-exclusive contrast (Section 4), and refutation, restriction and contraposition, as for exclusive contrast (Section 5). The markers are compared and the similarities and differences between them are highlighted taking as a starting point their lexical bases or sources, as summarized in Section 6 .

The different forms are illustrated with constructed examples for two operational reasons: using corpus examples, as was our first intention, would have made a crosslinguistic comparison very difficult to handle, since strictly parallel cases are very hard or even impossible to find; additionally, corpus examples would have increased the length of the paper, since every example would have needed a gloss in English.

The markers are presented in tables that allow a cross-linguistic comparison having as a tertium comparationis the source of the marker, which is indicated between quotation marks. The markers having the same or a similar source (e.g., Sp. al contrario, Cat. al contrari, It. al contrario, and Ro. din contra, which are all based on the respective word for "contrary") are arranged in the same row so that their similarity is highlighted. When there is no common origin in two or more languages but the elements can be roughly considered functional equivalents, the markers are also shown in the same row (as in the case of Sp. sin embargo, Cat. tanmateix, It. tuttavia and Ro. totuşi, "however"). Only unrelated markers in two or more languages are located in different rows.

The general aim of the paper is to provide an overall classification and description of the contrastive markers in the Romance languages at hand, as a first step that may be further supplemented with data from other languages, corpus examples and diachronic analyses. The comparison with other Romance languages, such as French or Portuguese, among others, is out of our present scope, but would certainly enrich the analysis ${ }^{3}$.

\section{Contrastive relations}

As already indicated, contrast is a negative coherence relation involving the comparison of two discourse segments that express propositional contents or states of affairs ${ }^{4}$ presented in an antonymic relation. When contrasting two segments, the speaker "not only combines but also compares the two co-occurring SoAs [states of affairs], conceiving them in their conflicting properties" (Mauri, 2008: 121).

3. The limited space allowed for this paper and the important fact that the authors are native speakers of the languages considered and have previously studied the field further justify the selection of these four languages.

4. Mauri (2008) uses the term "state of affairs" as a hyperonym for the words "situation", "event", "process" and "action": "The term 'state of affairs' is preferred because it does not characterize the entity in any particular sense, whereas 'situation' or 'process' may convey a static vs. dynamic connotation” (Mauri, 2008: 32). 
The main feature of contrastive coherence relations is their negative polarity (Sanders et al., 2018). Two discourse segments (S1 and S2) are in contrast when their meanings conflict either at the semantic or the pragmatic level. In the latter case, the opposition is established between inferences, not contents per se (Foolen, 1991: 83; Fuentes Rodríguez, 1998: 10), resulting in a construction by which S1 is somehow negated and S2 is asserted.

Several contrastive meanings can be differentiated. For instance, in the Hispanic grammar tradition (see, e.g., Acín Villa, 1993; Cuenca, 1991; Fuentes Rodríguez, 1998), two adversative meanings are distinguished, corresponding to the two general conjunctions that mark them: non-exclusive contrast or opposition (marked by Sp. pero "non-exclusive but") and exclusive contrast or correction (marked by Sp. sino "exclusive but").

1. Non-exclusive contrast implies that S1 and S2 are compatible (and thus the structure could be expressed with and), but S2 is in contrast with S1.

[1] a. SP: María es investigadora pero (también) da clase.

b. CAT: Maria és investigadora però (també) fa classe.

c. IT: Maria è ricercatrice $m a$ (anche) insegna.

d. RO: Maria este cercetătoare, dar (și) predă.

'Mary is a researcher but she (also) teaches.'

Non-exclusive contrast specifically occurs when S2 is in contrast to "an assumption that may be either read or inferred from previous information" (Lang, 2000: 246). From a pragmatic perspective, the two segments are anti-oriented, i.e., they are presented as arguments to contrary conclusions, S2 cancelling or mitigating a conclusion that could be derived from S1, even if S1 and S2 do not necessarily oppose lexically or semantically (Portolés, 1998: 140). Thus, S2 is considered a stronger argument for a certain conclusion and informatively more important.

2. Exclusive contrast or correction implies that $\mathrm{S} 1$ and $\mathrm{S} 2$ are not compatible (S1 is negated to assert S2) and provides the instruction to replace S1 by S2 in the current state of discourse information. Correction is characterized by the opposite polarity of the two segments: "The first SoA is overtly negated, while the second is positively asserted as a substitute of the first one" (Mauri, 2008: 143).

[2] a. SP: María no es profesora sino investigadora.

b. CAT: Maria no és professora sinó investigadora.

c. IT: Maria non è professoressa $m a$ ricercatrice.

d. RO: Maria nu este profesoară, $c i$ cercetătoare.

'Mary is not a teacher but a researcher.'

Correction activates the substitution of a proposition that the speaker/writer does not assume, which triggers polyphony (Ducrot, 1984; Fuentes Rodríguez, 1998: 15-16; Lopes \& Sousa, 2014: 21-22). 
Non-exclusive contrast can be further subdivided. Several authors differentiate weak contrast and general contrast, corresponding to the meanings expressed by contrastive whereas/while and but, respectively (e.g., Mauri, 2008). Weak contrast can be located in between addition and contrast, as shown by the possibility of reversing the segments and of substituting markers such as whereas/wbile by and. In the case of general contrast, expressed by but or equivalents, some authors distinguish semantic opposition (or contrastive comparison) from denial of expectation (or concessive contrast). For instance, Foolen (1991) and after him Izutsu (2008), among others, argue that examples such as John is rich but Peter is poor indicate semantic opposition or contrastive comparison, whereas examples such as John is short but strong deny an expectation. Whereas the first type of adversative relations contains two states of affairs that seem independent from one another, the second type contains two states of affairs related by at least co-occurrence, if not causality: "if the first state of affairs holds, the second state of affairs also normally holds. In the second example, the use of the word short triggers the expectation of weak, which is then denied by stating that John is strong" (Foolen, 1991: 83) ${ }^{5}$. Finally, there are some markers, corresponding to otherwise, which express conditional opposition (equivalent to "if not").

Considering these distinctions, we will differentiate weak contrast, opposition, concessive opposition and conditional opposition. These non-exclusive contrastive meanings are illustrated in English in [3] and will be further defined and exemplified in the following sections.

[3] a. His father helped him financially, whereas his mother gave him moral support.

b. I want to go with you but I have a lot of work.

c. She works very hard. Nonetheless, she did not get a promotion.

d. Julia must have a visa. Otherwise, she cannot fly to Havana.

Exclusive contrast can be further subdivided into three groups, namely, refutation, restriction and contraposition (see Cuenca, 2006). Refutation implies a "yes-no" relation between contrary poles. Restriction implies that $\mathrm{S} 1$ is presented as an incorrect or not completely adequate formulation and is substituted by S2. Contraposition arises when the marker indicates that $\mathrm{S} 1$ is to be discarded as not valid or is questioned with respect to S2. These exclusive contrastive meanings are illustrated in English in [4] and will be further defined and exemplified in the following sections.

[4] a. Paul is not British but Canadian.

b. Paul is British. At least, that is what he told me.

c. Paul told me he was British but, in reality, he is Canadian.

5. Even if denial of expectation can be thought of as a concessive relation, we think that the distinction between formulating the relation with but (or equivalent) and with a concessive conjunction (e.g., although) is significant and should be maintained (cf. Although Jobn is short, he is strong). 
In the following sections, contrastive markers, including conjunctions and other markers, will be classified. They are grouped according to the specific meaning they express, namely, non-exclusive contrast (including weak contrast, opposition, concessive opposition and conditional opposition, see Section 4) and exclusive contrast (including refutation, restriction and contraposition, see Section 5).

\section{Contrastive conjunctions in Spanish, Catalan, Italian and Romanian}

The Romance languages analyzed here use different conjunctions to express contrast, as shown in Table 1. The basic markers are marked in bold. The other markers exhibit some restrictions or specificities in use ${ }^{6}$.

\begin{tabular}{|c|c|c|c|c|c|}
\hline Meaning & Spanish & Catalan & Italian & Romanian & \\
\hline $\begin{array}{l}\text { Weak contrast } \\
\text { (non-exclusive) }\end{array}$ & $\begin{array}{l}\text { mientras que } \\
\text { ("while that") }\end{array}$ & $\begin{array}{l}\text { mentre que } \\
\text { ("while that") }\end{array}$ & $\begin{array}{l}\text { mentre } \\
\text { ("while that") }\end{array}$ & $\begin{array}{l}\text { în timp ce } \\
\text { ("in time that"), } \\
\text { în vreme ce } \\
\text { ("in time that"), } \\
\text { pe când } \\
\text { ("on when") }\end{array}$ & "while" \\
\hline & & & & iar & \\
\hline \multirow{2}{*}{$\begin{array}{l}\text { Opposition } \\
\text { Counter- } \\
\text { expectation } \\
\text { (non-exclusive) }\end{array}$} & $\begin{array}{l}\text { pero } \\
\text { (> "for this") }\end{array}$ & $\begin{array}{l}\text { però } \\
\text { (> “for this") }\end{array}$ & $\begin{array}{l}\text { però } \\
\text { (> “for this") }\end{array}$ & \multirow{2}{*}{$\begin{array}{l}\text { dar, } \\
\text { însă }\end{array}$} & \multirow{2}{*}{$\begin{array}{l}\text { non- } \\
\text { exclusive } \\
\text { "but" }\end{array}$} \\
\hline & $\begin{array}{l}\text { mas } \\
\text { (> "more") }\end{array}$ & $\begin{array}{l}\text { mes } \\
(>\text { "more") }\end{array}$ & $\begin{array}{l}\text { ma } \\
(>\text { "more") }\end{array}$ & & \\
\hline $\begin{array}{l}\text { Exclusive } \\
\text { contrast }\end{array}$ & $\begin{array}{l}\text { sino } \\
\text { ("if not") }\end{array}$ & $\begin{array}{l}\text { sinó } \\
\text { ("if not") }\end{array}$ & $\begin{array}{l}\text { ma } \\
\text { (> "more”), } \\
\text { bensì } \\
\text { (“well yes") }\end{array}$ & ci & $\begin{array}{l}\text { exclusive } \\
\text { "but" }\end{array}$ \\
\hline
\end{tabular}

Table 1 - Contrastive conjunctions in Spanish, Catalan, Italian and Romanian

6. As specified in the Introduction, the tables show the markers with the same or a similar source in the same row. The source or meaning is indicated between quotation marks; the sign ">" indicates a source that can be traced back to a different language, generally Latin, and is not obvious or transparent to the speakers anymore. When there is no common origin in two or more languages but the elements can be roughly considered functional equivalents, they are also displayed in the same row. The last column includes an approximate translation into English or gloss. 
Spanish and Catalan are both characterized as "languages with dedicated markers for counter-expectative and corrective contrast and no general marker expressing them both" (Mauri, 2008: 284). Spanish and Catalan also share two specific adversative conjunctions, namely, Sp. pero/sino and Cat. però/sinó, both free polysyllabic and polymorphemic markers derived from Latin causal (per hoc "for this") and negated conditional (si no "if not") constructions, respectively. The Latin causal phrase per hoc is also the source of It. però and Cat. però as a parenthetical connective (see Section 4).

Italian is considered an "and-but-or" language, along with some other Romance languages (French, Portuguese, Sardinian) or English (Mauri, 2008: 289-290). The conjunction $m a$, derived from the Latin adverb magis ("more"), can express both exclusive and non-exclusive contrast (Mazzoleni, 2000 and 2015; Serianni, 1988: 454). A parallel form exists in Portuguese (mas) or French (mais) (Ducrot \& Vogt, 1979), and it used to exist in Spanish (mas) and Catalan (mes), although the use of these markers is now mostly considered literary or obsolete.

Like Spanish and Catalan, Romanian has a dedicated marker for corrective contrast (Mauri, 2008: 115), i.e., the conjunction ci, derived from Old Romanian $c e<$ Lat. quid (see DULR). Two connectives, dar and $\hat{\imath} n s a \breve{a}$, can be used for relations of opposition and counter-expectation. The system is completed by the conjunction iar and a series of temporal markers that can be used to signal weak contrast. The conjunction iar, which is absent in the other languages under analysis, occupies a place at the border between addition and contrast, signaling simultaneous/atemporal relations as well as weak contrast (Mauri, 2008: 113; Postolea, 2018).

All four languages can express weak contrast by means of conjunctions that developed from a simultaneity meaning, i.e. Sp. mientras que, Cat. mentre que, It. mentre, Ro. în timp celîn vreme ce/pe când ("while/whereas"), a development that can also be identified in Fr. alors que and tandis que, or in En. while (Mauri, 2008: 292).

In conclusion, Spanish, Catalan and Romanian exhibit a system with three or more conjunctions to express contrastive meanings; Italian can express contrast with two main conjunctions (mentre and $m a$ ) and underspecifies the difference between exclusive and non-exclusive "strong" contrast: the linguistic context activates an exclusive or a non-exclusive reading of an adversative clause including $m a$ ("but"). Italian also has specific markers to express counter-expectation (però) and exclusive contrast (bensi). These dedicated markers are not always used as conjunctions and alternate - and sometimes combine - with the general conjunction $m a$; however, as will be highlighted in the following sections, they exhibit more restrictions of use than ma.

In addition to conjunctions, there is a large group of markers that express contrast. In the following sections, the most important markers in the four languages considered will be identified and illustrated. 


\section{Non-exclusive contrast markers}

Non-exclusive contrast markers indicate (either semantic or pragmatic) contrast between two compatible segments. They are all commutable by non-exclusive but (e.g., Sp. pero). The group includes four specific meanings, namely, weak contrast, opposition, concessive opposition and conditional opposition.

\subsection{Weak contrast markers}

Weak contrast markers show two states of affairs as simultaneous but somehow contrasting in a very general fashion. In fact, these sequences can generally express additivity and the segments can be reversed, which clearly indicates a low degree of contrast.

[5] a. SP: Él es tímido, mientras que su hermana es extrovertida.

b. CAT: Ell és tímid, mentre que la seva germana és extrovertida.

c. IT: È timido, mentre sua sorella è estroversa.

d. RO: El e timid, iar/în timp celîn vreme ce/pe când sora lui e extravertită.

'He is shy while his sister is outspoken.'

The main markers indicating weak contrast are shown in Table $2^{7}$.

\begin{tabular}{|c|c|c|c|c|}
\hline Spanish & Catalan & Italian & Romanian & \\
\hline \multirow[t]{2}{*}{$\begin{array}{l}\text { mientras que }(\mathrm{Cj}) \\
\text { ("while that") }\end{array}$} & \multirow[t]{2}{*}{$\begin{array}{l}\text { mentre que }(\mathrm{Cj}) \\
\text { ("while that") }\end{array}$} & \multirow[t]{2}{*}{$\begin{array}{l}\text { mentre }(C \mathrm{j}) \\
\text { ("while") }\end{array}$} & $\begin{array}{l}\text { în timp ce }(\mathrm{Cj}) \\
\text { ("in time that"), } \\
\text { în vreme ce }(\mathrm{Cj}) \\
\text { ("in time that"), } \\
\text { pe când }(\mathrm{Cj}) \\
\text { ("on when") }\end{array}$ & "while" \\
\hline & & & $\operatorname{iar}(\mathrm{Cj})$ & \\
\hline $\begin{array}{l}\text { por otra parte, } \\
\text { por su parte } \\
\text { ("for another/its } \\
\text { part") }\end{array}$ & $\begin{array}{l}\text { d'altra banda } \\
\text { (“of a different } \\
\text { part") }\end{array}$ & $\begin{array}{l}\text { d'altra parte, } \\
\text { d'altro lato, } \\
\text { d'altro canto, } \\
\text { d'altronde } \\
\text { ("of a different } \\
\text { part/side") }\end{array}$ & $\begin{array}{l}\text { pe de altă parte, } \\
\text { de cealaltă parte } \\
\text { ("on another/the } \\
\text { other part") }\end{array}$ & $\begin{array}{l}\text { "on the } \\
\text { other hand" }\end{array}$ \\
\hline
\end{tabular}

Table 2 - Weak contrast markers

7. When the marker is a conjunction, the indication " $(\mathrm{Cj})$ " follows. Otherwise, the marker is a parenthetical connective. 
The four languages include markers that have developed a contrastive meaning from temporal conjunctions indicating simultaneity used in a context of opposing propositional contents. Romanian coordinating conjunction iar is atypical when compared to other Romance languages ${ }^{8}$. GALR I and several scholars describe iar as an adversative/contrast marker specialized in signaling "unoriented semantic contrast" or "theme contrast" (Zafiu, 2005) and characterized by a "double contrastiveness constraint" (Bîlbîie \& Winterstein, 2011). However, recent studies seem to point to the fact that, in line with Mauri (2008), iar is an additive marker (Postolea, 2018) that serves as a "pragmatic discourse organizer" (Vasilescu, 2010) signaling contrast only in some of its uses. In [6a] iar marks weak contrast, whereas in [6b] the idea of contrast is absent, and the relation could be described as an "and-so" one in Sweetser's terms (1990: 88).

[6] a. Angela este scriitoare, iar sora ei este cântăreață. 'Angela is a writer and her sister is a singer.'

b. Situația economică s-a înrăutățit, iar oamenii și-au pierdut slujbele. 'The state of the economy worsened and (so) people lost their jobs.'

Along with connectives derived from temporal conjunctions indicating simultaneity, all four languages can express weak contrast by means of one or more parenthetical connectives based on a spatial prepositional phrase similar to "on the other hand" 9 .

[7] a. SP: El diseño se realizará en Alemania. La fabricación, por otra parte, se hará en China.

b. CAT: El disseny es realitzarà a Alemanya. La fabricació, d'altra banda, es farà a la Xina.

c. IT: Sarà progettato in Germania. La fabbricazione, d'altro canto, sarà in Cina.

d. RO: Design-ul va fi realizat în Germania. Fabricarea, pe de altă parte, va avea loc în China.

'It will be designed in Germany. Its fabrication, on the other hand, will be in China.'

\subsection{Opposition markers}

Opposition markers indicate contrast between two compatible segments, but pragmatically S2 is considered a stronger argument for a certain conclusion and informatively more important (Fuentes Rodríguez, 1998; Portolés, 1998). As a

8. There are several theories regarding the origin of iar - e.g., Lat. *era (see DER) or Lat. *ea bora (Densuşianu cited in Niculescu, 1965; Foolen, 1991) - but none has been proven yet. This conjunction has also been compared to the Russian $a$ (Bîlbîie \& Winterstein, 2011).

9. These markers can be used contrastively but also non-contrastively, as sequencing devices (Fuentes Rodríguez, 1998: 63). 
result, the order reversal of the segments implies semantic-pragmatic changes and activates contrary conclusions ${ }^{10}$.

[8] I want to go with you but I have lots of work (conclusion: "I am not going"). I have lots of work but I want to go with you (conclusion: "I am going").

The markers indicating opposition are shown in Table 3.

\begin{tabular}{|c|c|c|c|c|}
\hline Spanish & Catalan & Italian & Romanian & \\
\hline $\begin{array}{l}\text { pero }(\mathrm{Cj}) \\
\text { (> "for this") }\end{array}$ & $\begin{array}{l}\text { però }(\mathrm{Cj}) \\
\text { (> "for this") }\end{array}$ & $\begin{array}{l}\text { ma }(\mathrm{C} j) \\
(>\text { "more") }\end{array}$ & $\begin{array}{l}\operatorname{dar}(C \mathrm{j}), \\
\text { insă }(C \mathrm{j})\end{array}$ & $\begin{array}{l}\text { non-exclusive } \\
\text { "but" }\end{array}$ \\
\hline \multirow{2}{*}{$\begin{array}{l}\text { sin embargo } \\
\text { (“without } \\
\text { impediment”) }\end{array}$} & $\begin{array}{l}\text { tanmateix } \\
\text { ("so same") }\end{array}$ & $\begin{array}{l}\text { tuttavia } \\
\text { (“all way") }\end{array}$ & $\begin{array}{l}\text { totuşi } \\
\text { ("everything and") }\end{array}$ & "however" \\
\hline & & $\begin{array}{l}\text { sennonché } \\
\text { ("if not that") }\end{array}$ & & $\begin{array}{l}\text { "except for } \\
\text { (the fact } \\
\text { that)" }\end{array}$ \\
\hline $\begin{array}{l}\text { en cambio } \\
\text { ("in change") }\end{array}$ & $\begin{array}{l}\text { en canvi } \\
\text { ("in change") }\end{array}$ & $\begin{array}{l}\text { invece } \\
\text { ("in place/stead") }\end{array}$ & $\begin{array}{l}\text { în schimb } \\
\text { ("in change") }\end{array}$ & "instead" \\
\hline $\begin{array}{l}\text { por el contrario, } \\
\text { por contra } \\
\text { ("for the } \\
\text { contrary") }\end{array}$ & $\begin{array}{l}\text { al contrari, } \\
\text { per contra } \\
\text { ("at/for the } \\
\text { contrary") }\end{array}$ & $\begin{array}{l}\text { al contrario } \\
\text { ("at the } \\
\text { contrary") }\end{array}$ & $\begin{array}{l}\text { dimpotrivă, } \\
\text { din contra/din } \\
\text { contră } \\
\text { ("from the } \\
\text { contrary") }\end{array}$ & $\begin{array}{l}\text { "but"/“on the } \\
\text { other hand" }\end{array}$ \\
\hline $\begin{array}{l}\text { ahora (bien) } \\
\text { ("now (good)") }\end{array}$ & $\begin{array}{l}\text { ara (bé) } \\
\text { ("now (good)") }\end{array}$ & & & $\begin{array}{l}\text { non-exclusive } \\
\text { "but" }\end{array}$ \\
\hline $\begin{array}{l}\text { eso sí } \\
\text { ("this yes") }\end{array}$ & $\begin{array}{l}\text { això sí } \\
\text { ("this yes") }\end{array}$ & & & $\begin{array}{l}\text { non-exclusive } \\
\text { "but" }\end{array}$ \\
\hline
\end{tabular}

Table 3 - Opposition markers

As already commented on, the general opposition conjunctions are Sp. pero and Cat. però, both derived from a Latin prepositional phrase with causal meaning (Lat. per hoc "for this") (Cuenca, 1992-1993; Muñoz Garrigós, 1981), It. ma, derived from Lat. magis "more" used as a comparative (see Marconi \& Bertinetto, 1984; Proietti, 2015), and Ro. dar and însă. All these forms correspond to non-exclusive but.

[9] a. SP: Es un libro interesante pero es demasiado caro.

b. CAT: És un llibre interessant però és massa car.

c. IT: $\grave{E}$ un libro interessante $m a$ è troppo costoso.

d. RO: Este o carte interesantă, dar/insă este prea scumpă.

'It is an interesting book but it is too expensive.'

10. Order reversal allows to differentiate opposition (counter-argumentative) from weak contrast, which is the only contrastive relation that admits it. 
Spanish and Catalan also had conjunctions derived from Lat. magis (Sp. mas, Cat. mes) but these forms are not used anymore or have very restricted contexts of use (Muñoz Garrigós, 1981). In Italian, però can act either as a conjunction or as a coordinating adverbial or parenthetical connective, but its use is most of the time related to counter-expectative meanings (see Section 4). In Romanian, opposition can be expressed by the "quasi-synonymous" (GALR I; Zafiu, 2005) couple of conjunctions dar and $\hat{\imath} n s \breve{a}^{11}$.

In addition to the general conjunctions already mentioned, there are a number of connectives that indicate different degrees of opposition and can either combine or substitute opposition conjunctions. Some markers are very general, as the ones in [10], while others introduce a more specific instruction.

[10] a. SP: Es un libro interesante (pero), sin embargo, es demasiado caro.

b. CAT: És un llibre interessant (però), tanmateix, és massa car.

c. IT: Ė un libro interessante; (ma,) tuttavia, è troppo costoso. / ...sennonché è troppo costoso.

d. RO: Este o carte interesantă; (dar,) totuşi, este prea scumpă.

'It is an interesting book; (but,) however, it is too expensive ${ }^{12}$.'

The markers based on the noun change (Sp. en cambio, Cat. en canvi, Ro. in schimb) and Italian invece ("in place/stead") focus on the contrastive comparison in two segments sharing a topic (example [11]) ${ }^{13}$.

[11] a. SP: De pequeño le gustaba el baloncesto. Ahora, en cambio, le gusta más el futbol.

b. CAT: De petit li agradava el bàsquet. Ara, en canvi, li agrada més el futbol.

c. IT: Da bambino gli piaceva il basket. Ora, invece, gli piace di più il calcio.

d. RO: Când era mic îi plăcea baschetul. Acum, in schimb, îi place mai mult fotbalul.

'As a child he liked basketball. But now he likes football better.'

The markers based on the word contrary highlight the complementarity of the segments as two opposing ("contrary") parts of a whole (example [12]). They are similar to correction markers in that they are polar (Fuentes Rodríguez, 1998: 57),

11. In Romanian dar can be considered a primary contrast marker. It has unknown origins: DER quotes

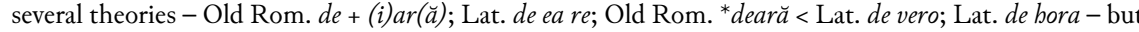
none has been agreed upon so far. The marker $\hat{\imath} n s a ̆$ exhibits a more complex behavior. Although $\hat{\imath} n s \breve{a}$ is said to originate in Lat. ipsa (see DER), recent works have pointed out that this pronominal origin has not been fully confirmed yet (Zafiu, 2005).

12. Both It. tuttavia and Ro. totuşi can also express concessive opposition depending on the context. Sennonché is roughly equivalent to $m a$, but it introduces an exceptive meaning (“except for the fact that..."). Like $m a$, it can be used intrasententially and intersententially.

13. On invece in Italian as compared with en cambio in Spanish, see Sainz (2015). 
but they can be replaced by the non-exclusive conjunction (e.g., Sp. pero), not by the exclusive one (e.g., Sp. sino), which clearly indicates no incompatibility between the two segments.

[12] a. SP: El precio de la luz ha aumentado en los últimos años. Los sueldos, por el contrario, han disminuido.

b. CAT: El preu de la llum ha augmentat en els darrers anys. Els sous, al contrari/ per contra, han disminuï.

c. IT: La bolletta elettrica è aumentata negli ultimi anni. I salari, al contrario, sono diminuiti.

d. RO: Prețul curentului electric a crescut în ultimii ani. Salariile, dimpotrivă/din contraldin contră, au scăzut.

'The electricity bill has increased in the last years. Wages, on the contrary, have decreased.'

The markers based on change and on contrary, common to all four languages, activate a contrastive comparison as defined by Foolen: "two comparable states of affairs are typically contrasted by taking two topics and predicating them to differ in some respect" (Foolen, 1991: 83) ${ }^{14}$.

Spanish and Catalan have markers including a deictic plus a positive polarity marker (Sp. abora bien, eso sí; Cat. ara (bé), això sì). These markers are mainly used at the text level and introduce contrary conclusions to the ones derived from S1. Spanish ahora bien and Cat. ara (bé) (example [13]) intensify S2 as a strong argument for a certain conclusion, whereas Sp. eso sí and Cat. això sí (example [14]) mitigate the argumentative force of S1 (Portolés, 1998: 140).

[13] a. SP: Pensaba ir a verlo mañana. Abora bien, si no quiere visitas, no iré.

b. CAT: Pensava a anar a veure'l demà. Ara (bé), si no vol visites, no hi aniré.

'I intended to visit him tomorrow. But, if he doesn't want any visits, I won't go.'

[14] a. SP: Me ayudó a limpiar la casa. Eso sí, se lo tuve que pedir varias veces.

b. CAT: Em va ajudar a netejar la casa. Això sí, li ho vaig a ver de demanar diverses vegades.

'He helped me clean the house. But I had to ask him to do so several times ${ }^{15}$.'

14. See also Lopes and Sousa (2014) on ao invés in Portuguese, which exhibits a similar behavior. On al contrario in Italian as compared with al contrario in Spanish, see Sainz (2015).

15. Romanian does not have grammaticalized compound markers including a temporal deictic and a positive polarity marker. However, the same opposition effect may be obtained by using $d a$ ("yes") before the conjunction $d a r$ or its (speech) version $d a$ ' - a combination specific to spoken, informal Romanian: M-a ajutat să fac curat în casă. Da, dar/da' a trebuit să îl rog de mai multe ori ca să o facă ("He helped me clean the house. Yes, but I had to ask him to do so several times"). 


\subsection{Concessive opposition markers}

An important group of opposition markers do not express only counterargumentation, as in the case of opposition markers, but also indicate denial of expectation, as a concessive marker would do. This is the case of nevertheless in English, as shown in [15]:

[15] She was late. Nevertheless, she was allowed to come in.

The assertion of S2 cancels the presupposition that can be derived from S1 and is in contrast to "an assumption that may be either read or inferred from previous information" (Lang, 2000: 246). In Mauri's words, S2 "constitutes the source from which to look for a pertinent assumption that meets the condition of contrast, and this assumption constitutes the target" (Mauri, 2008: 125).

Opposition involves "no conflicting expectations" (Mauri, 2008: 122), whereas concession (denial of an expectation or counter-expectation), like correction, "involves some ground assumption or expectation" (Izutsu, 2008: 661) that "is implicit in the sentence itself or in the context" (Mauri, 2008: 144).

The conflict characterizing counter-expectative contrast does not depend on the antonymic semantics of the linked states of affairs, but only on the denial of an implicit assumption, and this is what motivates the distance between counterexpectative and oppositive contrast in the conceptual space (Mauri, 2008: 144).

The constructions containing concessive opposition markers can thus be paraphrased by the general adversative conjunction (introducing S2) or by a concessive conjunction (introducing S1), as shown in [16].

[16] a. She was late. Nevertheless, she was allowed to come in.

b. She was late, but she was allowed to come in.

c. Although she was late, she was allowed to come in.

The markers indicating concessive opposition are shown in Table $4^{16}$.

As Table 4 highlights, concessive opposition markers frequently include quantifiers, demonstratives and general nouns:

Quantifiers: tot/todo/tot/toate "all"; qualsevol/cualquier/ogni/orice "any"

Demonstratives: aixòleso/acestea "this/these"; así/així/cosílaşa "so"

General nouns: cas/caso/caz "case"; manera/modo, forma(s)/formes/via "way"

16. As indicated in Section 2, some authors consider that non-exclusive but can also have this value, but we think that, at least in the languages analyzed here, this value is more clearly conveyed by specific markers. 


\begin{tabular}{|c|c|c|c|c|}
\hline Spanish & Catalan & Italian & Romanian & \\
\hline & $\begin{array}{l}\text { però } \\
\text { (parenthetical), } \\
\text { per (ai)xò } \\
\text { (> "for this") }\end{array}$ & $\begin{array}{l}\text { però } \\
\text { (parenthetical) } \\
\text { (> "for this") }\end{array}$ & $\begin{array}{l}\text { însă } \\
\text { (parenthetical) }\end{array}$ & "though" \\
\hline \multirow{4}{*}{$\begin{array}{l}\text { no obstante } \\
\text { ("notwithstand- } \\
\text { ing") }\end{array}$} & \multirow{4}{*}{$\begin{array}{l}\text { no obstant } \\
\text { això/ } \\
\text { això no obstant } \\
\text { ("notwithstand- } \\
\text { ing this") }\end{array}$} & $\begin{array}{l}\text { ciononostante } \\
\text { ("this notwith- } \\
\text { standing") }\end{array}$ & & \multirow{4}{*}{$\begin{array}{l}\text { "nevertheless", } \\
\text { "notwithstand- } \\
\text { ing" }\end{array}$} \\
\hline & & $\begin{array}{l}\text { eppure } \\
\text { ("and yet") }\end{array}$ & & \\
\hline & & $\begin{array}{l}\text { nondimeno } \\
\text { ("not of less") }\end{array}$ & & \\
\hline & & $\begin{array}{l}\text { malgrado ciò } \\
\text { ("in spite of } \\
\text { this") }\end{array}$ & & \\
\hline \multirow{2}{*}{$\begin{array}{l}\text { con todo } \\
\text { (y con eso) } \\
\text { ("with all"), } \\
\text { a pesar de/ } \\
\text { pese a todo } \\
\text { ("in spite of all") }\end{array}$} & \multirow{2}{*}{$\begin{array}{l}\text { (tot) amb tot } \\
\text { ("(all) with all"), } \\
\text { malgrat tot } \\
\text { ("in spite of all") }\end{array}$} & & $\begin{array}{l}\text { cu toate acestea } \\
\text { ("with all } \\
\text { these") }\end{array}$ & $\begin{array}{l}\text { "all in all", } \\
\text { "notwithstand- } \\
\text { ing" }\end{array}$ \\
\hline & & $\begin{array}{l}\text { malgrado tutto } \\
\text { ("in spite of all") }\end{array}$ & $\begin{array}{l}\text { totuşi } \\
\text { ("everything } \\
\text { and") }\end{array}$ & "yet", "still" \\
\hline $\begin{array}{l}\text { aun así } \\
\text { (“even so”) }\end{array}$ & $\begin{array}{l}\text { tot i (amb) } \\
\text { això, tot i així, } \\
\text { així i tot } \\
\text { ("all and this/ } \\
\text { so") }\end{array}$ & $\begin{array}{l}\text { anche così } \\
\text { ("even so") }\end{array}$ & $\begin{array}{l}\text { chiar şi aşa/ } \\
\text { chiar aşa } \\
\text { ("even and so/ } \\
\text { even so") }\end{array}$ & “even so/still” \\
\hline $\begin{array}{l}\text { de todas } \\
\text { maneras/ } \\
\text { formas, de } \\
\text { todos modos, } \\
\text { de cualquier } \\
\text { manera } \\
\text { ("in all/any } \\
\text { way") }\end{array}$ & $\begin{array}{l}\text { de tota manera/ } \\
\text { de totes } \\
\text { maneres } \\
\text { ("in all way(s)") }\end{array}$ & $\begin{array}{l}\text { comunque } \\
\text { (> in any way") }\end{array}$ & $\begin{array}{l}\text { oricum } \\
\text { (“anyhow") }\end{array}$ & "anyway" \\
\hline $\begin{array}{l}\text { en todo/ } \\
\text { cualquier caso } \\
\text { ("in all/any } \\
\text { case") }\end{array}$ & $\begin{array}{l}\text { en tot/ } \\
\text { qualsevol cas } \\
\text { ("in all/any } \\
\text { case") }\end{array}$ & $\begin{array}{l}\text { in ogni caso } \\
\text { ("in any case") }\end{array}$ & $\begin{array}{l}\text { în orice caz/ } \\
\text { în tot cazul } \\
\text { ("in all/any } \\
\text { case") }\end{array}$ & "in any case" \\
\hline $\begin{array}{l}\text { sea como sea/ } \\
\text { fuere } \\
\text { ("be it as it } \\
\text { were") }\end{array}$ & $\begin{array}{l}\text { sigui com sigui/ } \\
\text { vulgui } \\
\text { ("be it as it } \\
\text { were/wants") }\end{array}$ & $\begin{array}{l}\text { sia come sia } \\
\text { ("be it as it } \\
\text { were") }\end{array}$ & $\begin{array}{l}\text { orice ar fi/ } \\
\text { fie ce-o fi } \\
\text { ("whatever } \\
\text { might be"/“be it } \\
\text { as it may") }\end{array}$ & $\begin{array}{l}\text { "no matter } \\
\text { what" }\end{array}$ \\
\hline
\end{tabular}

Table 4 - Concessive opposition markers 
All the previous elements have an endophoric nature, which is related to the concessive-adversative meaning that characterizes them. The examples below show how these markers work in the languages of interest ${ }^{17}$.

[17] a. CAT: Va dir que tornaria aviat. No vindrà, però/per (ai)xò.

b. IT: Ha detto che tornava subito. Non verrà, però ${ }^{18}$.

c. RO: A spus că se va întoarce în curând. Nu va veni însă.

'He said that he'll be back soon. He won't come, though.'

[18] a. SP: Llegó tarde. No obstante, le permitieron entrar.

b. CAT: Va arribar tard. No obstant (això)/Això no obstant, li van permetre entrar ${ }^{19}$.

c. IT: Ł̇ arrivato tardi. Ciononostante/Nondimeno/Eppure, lo hanno fatto entrare.

'He was late. Nevertheless, he was allowed to come in.'

[19] a. SP: Ganaba millones, pero, con todo (y con eso)/a pesar de todo/pese a todo, no se sentía feliz.

b. CAT: Guanyava milions però, amb tot/malgrat tot, no se sentía feliç.

c. IT: Guadagnava millioni, ma, malgrado tutto, non era felice.

d. RO: Câsștiga milioane, dar, cu toate acestealtotuşi, nu era fericită.

'She earned millions but, still, she wasn't happy.'

[20] a. SP: Hacía trampas y, aún así, perdió el dinero.

b. CAT: Feia trampes i, tot i (amb això)/tot i aixílaixí $i$ tot, va perdre els diners.

c. IT: Ha barato e anche cosi ha perso i soldi.

d. RO: A trișat și, chiar (și) aşa, a pierdut banii.

'He cheated and, even so, he lost the money.'

[21] a. SP: No me han invitado, pero, de todas maneras/de todas formas/de todos modos/de cualquier manera, no pensaba ir.

b. CAT: No m'hi han convidat, però, de tota maneralde totes maneres, no pensava anar-hi.

c. IT: Non mi hanno invitato, ma comunque non avevo intenzione di andare.

d. RO: Nu am fost invitat, dar, oricum, nu voiam să merg.

'I wasn't invited but, in any case, I didn't intend to go.'

17. A detailed analysis of all these markers would exceed the length of this paper. However, they are similar but not completely equivalent in all contexts. Some can even alternate with opposition markers in some cases.

18. On the diachrony of però in Italian, see Giacalone Ramat \& Mauri (2008 and 2012); Proietti (2015).

19. On the diachrony of no obstant això in Catalan, see Garachana (2019). 
[22] a. SP: Llevaremos bebida a la fiesta. En todo/cualquier caso, no llegaremos con las manos vacías.

b. CAT: Portarem beguda a la festa. En tot/qualsevol cas, no hi arribarem amb les mans buides.

c. IT: Porteremo da bere alla festa. In ogni caso non arriveremo a mani vuote.

d. RO: Vom aduce băutură la petrecere. In orice caz/în tot cazul, nu vom veni cu mâna goală.

'We will take drinks to the party. In any case, we won't arrive empty-handed.'

[23] a. SP: No te preocupes. Sea como sealfuere, saldremos adelante.

b. CAT: No t'amoïnis. Sigui com sigui/vulgui, ens en sortirem.

c. IT: Non ti preoccupare. Sia come sia, tiriamo avanti.

d. RO: Nu-ți fă griji. Orice ar fi/Fie ce-o fi, vom merge mai departe.

'Don't worry. However it may be, we will go on.'

The structures illustrated above (examples [17]-[23]) correspond to meanings that are both adversative and concessive. As Cuenca (2006) argues, adversativity highlights the antithesis of the relation whereas concession highlights the thesis or origin of a binary relation. In other words, the adversative schema focuses on $\mathrm{Q}$, that is, on the antithesis of a thesis-antithesis relationship ([P but $\mathrm{Q}]$ ). The concessive schema focuses on the thesis, which corresponds to a negated cause, that is, a cause that did not produce the presumed effect ([although P (thesis/cause), Q (antithesis/ negated effect)]).

If the ordering of the segments in a contrastive relationship is reversed (that is, S2 expresses the negated thesis, not the antithesis), the concessive schema is reinterpreted as adversative and the concessive opposition meaning arises. When the thesis (in canonical order corresponding to S1) is linearly located in second position, (pure) concession expressed by using a concessive conjunction can only be expressed at the sentence level (i.e., as a subordinate in a reversed order). At the text level, concessive meanings cannot be expressed by means of conjunctions ${ }^{20}$. Only concessive opposition markers can fulfill this function. These markers often have an endophoric origin, by which the first segment is retrieved in the second segment.

[24] a. Although she earned millions, she wasn't happy. (canonical order)

b. She wasn't happy, although she earned millions. (reversed order)

c. She earned millions. Still/Even so, she wasn't happy. (text level construction)

Finally, it is worth noticing the case of però, which raises an interesting issue that can only be sketched here. Italian però and Catalan però share the possibility

20. As a result, concession is differently expressed at the sentence and at the text level. At the sentence level, concession is expressed by means of subordination and the subordinate clause can either precede or follow the matrix sentence. At the text level, the second segment cannot be expressed as a negated cause or thesis with respect to a previous first segment by means of a concessive conjunction. 
of acting as a conjunction (example [25]) or as a parenthetical connective when located in medial (example [26]) or final position (example [27]).

[25] IT: Piero gioca bene, però perde in continuazione.

CAT: En Pere juga bé, però perd sempre.

'Peter is a good player, but he always loses.'

[26] IT: Piero gioca bene, a me però non piace come gioca.

CAT: En Pere juga bé; a mi, però, no m'agrada com juga.

'Peter is a good player; I don't like, however, how he plays.'

[27] IT: Piero gioca bene, perde in continuazione però.

CAT: En Pere juga bé; perd sempre, però/per (ai)xò.

'Peter is a good player; he always loses, though.'

As a conjunction, like in [25], It. però alternates with the general conjunction $m a$, whereas in Catalan però is the general non-exclusive contrastive marker. In non-initial position, both the categorical functioning and the meaning of però change in both languages. Non-initial però encodes a contrast generated by the denial of some expectation - "contrasto controaspettativo" (Scorretti, 1988: 230231) ${ }^{21}$. Syntactically, as argued by Scorretti (1988: 231-232), It. però, unlike ma, may co-occur with another coordinating marker such as $e$ "and":

[28] Mario gioca bene e però perde.

'Mario plays well and yet he loses.'

Thus, according to the basic criterion for distinguishing adverbial from pure coordinating devices, $m a$ is classified as a pure coordinating marker, while però, in contexts as those in [28], is considered an adverbial coordinating marker (Dik, 1968: 34) or a parenthetical connective (Cuenca, 1992-1993, 2006, 2013).

In the case of Catalan, però is polyfunctional: it is a conjunction when introducing S2 and it is a parenthetical concessive connective when used in medial or in final position, although in these cases it does not combine with any conjunction. It can alternate with concessive per això (literally, "for this", often pronounced as perxò, with phonetic reduction), especially in final position.

In Romanian, însă is somehow equivalent to però. In fact, the distinction between dar and $\hat{\imath} n s a ̆$ mirrors that between $m a$ and però in Italian, as $\hat{\imath} n s a ̆$, like però, is characterized by a flexible position within the clause (Zafiu, 2005). However, if però can combine with the conjunction "and", the combination *și insă is not acceptable in Romanian.

21. Leaving the exclamative use aside (però! - "Wow!"), counter-expectative contrast is the only function associated with It. però as a clause linking device (Giacalone Ramat \& Mauri, 2008: 306). 


\subsection{Conditional opposition markers}

A group of markers indicate contrast in a hypothetical situation.

[29] You must tell me the truth. Otherwise, you will be punished.

In examples like [29], S2 is roughly equivalent to the paraphrase "if not S1, then S2".

The markers indicating conditional opposition are shown in Table 5.

\begin{tabular}{|l|l|l|l|l|}
\hline Spanish & Catalan & Italian & Romanian & \\
\hline $\begin{array}{l}\text { de otro modo } \\
\text { ("of another } \\
\text { way") }\end{array}$ & $\begin{array}{l}\text { altrament } \\
\text { ("otherwise") }\end{array}$ & $\begin{array}{l}\text { altrimenti } \\
\text { ("otherwise") }\end{array}$ & $\begin{array}{l}\text { altminteri/altfel } \\
\text { ("otherwise/ } \\
\text { other way") }\end{array}$ & \\
\hline $\begin{array}{l}\text { si no } \\
\text { ("if not") }\end{array}$ & $\begin{array}{l}\text { si no } \\
\text { ("if not") }\end{array}$ & $\begin{array}{l}\text { se no } \\
\text { ("if not") }\end{array}$ & $\begin{array}{l}\text { dacă nu/de nu } \\
\text { ("if not") }\end{array}$ & \multirow{2}{*}{ "otherwise" } \\
\cline { 1 - 2 } $\begin{array}{l}\text { en caso } \\
\text { contrario } \\
\text { ("in a contrary } \\
\text { case") }\end{array}$ & $\begin{array}{l}\text { en cas contrari } \\
\text { ("in a contrary } \\
\text { case") }\end{array}$ & $\begin{array}{l}\text { in caso } \\
\text { contrario } \\
\text { ("in a contrary } \\
\text { case") }\end{array}$ & $\begin{array}{l}\text { in caz contrar } \\
\text { ("in a contrary } \\
\text { case") }\end{array}$ & \\
\hline
\end{tabular}

Table 5 - Conditional opposition markers

In all the languages studied, the markers include explicit negation (no/nu) or implicit negation, related to the presence of the indefinite "other" (otrolaltr-lalt-), indicating alternative, or the adjective contrario/contrari/contrar "contrary" 22.

[30] a. SP: Necesito hablar contigo; de otro modo/si no, no te habría llamado a estas horas.

b. CAT: Necessito parlar amb tu; altrament/si no, no t'hauria trucat a aquestes hores.

c. IT: Ho bisogno di parlarti; altrimenti/se no non avrei chiamato così tardi.

d. RO: Trebuie să-ți vorbesc; altfel/altminteri, nu aş fi sunat aşa de târziu.

'I need to talk to you; otherwise, I wouldn't have called so late.'

[31] a. SP: Espero que lleguemos a un acuerdo. En caso contrario/Si no, tendremos un problema.

b. CAT: Espero que arribem a un accord. En cas contrari/Si no, tindrem un problema.

c. IT: Spero troveremo un accordo. In caso contrario/Se no avremo un problema.

d. RO: Sper că vom ajunge la un acord. In caz contrar/Dacă nu/De nu, vom avea o problemă.

'I hope that we can finally agree. Otherwise, we will have a problem.'

22. As for a parallel marker in French, see Lamiroy \& Charolles (2005) on autrement. 
In Spanish and Catalan, the marker si no can alternate with the other two markers, but substitution between Sp. de otro modo and en caso contrario, Cat. altrament and en cas contrari and It. altrimenti and in caso contrario, seems to be more restricted.

Romanian dacă nu/de nu cannot alternate with altfel/altminteri. As shown in Ștefănescu and Postolea (2018), when encoding a conditional opposition relation, the synonymous couple altfel/altminteri triggers a cognitive process that invites the addressee to refer back to $\mathrm{S} 1$ and infer from it a protasis with a meaning opposite to the one actually asserted. Thus, S2 becomes the apodosis of this inferred protasis, not of the actual content in $\mathrm{S} 1^{23}$. The couple dacă nu/de nu seems to operate directly at the level of the propositional content: it reasserts the content in S1, expressing it in the form of a negative protasis. Rather than triggering an inferential process, the couple dacă/de nu works as an abridging device that allows for S1 not to be repeated ${ }^{24}$.

\section{Exclusive contrast markers}

Exclusive contrast or correction is based on the incompatibility between two segments. As Mauri (2008: 144) indicates, "the antonymic conflict typical of correction is determined by the opposite polarity of the linked SoAs, since the first one is overtly denied and the second one is positively asserted as the substitute". In other words, the incompatibility of the segments is explicitly expressed by a polemic negation (Anscombre \& Ducrot, 1977) that "renders the first segment (S1) invalid and anticipates the occurrence of a valid alternative to S1" (i.e., S2) (Izutsu, 2008: 668).

[32] a. SP: John no es americano sino inglés.

b. CAT: John no és americà sinó anglès.

c. RO: John nu este american, $c i$ englez.

d. IT: John non è americano, ma/bensì inglese.

'John is not American, but English.'

The corrective relation consists of two segments (S1 and S2) specified as "corrigendum" and "corrigens", with the former being rejected by a morphologically independent negative and the latter being substituted for the former (Izutsu, 2008: 668-669). Correction triggers a formulative polyphonic operation, by which the speaker assumes S2 but not S1, which can be attributed to the interlocutor or to general knowledge (Fuentes Rodríguez, 1998).

From a cognitive perspective, correction is a comparison operation between two different, mutually exclusive, items of a shared domain: S2 asserts a semantic content that rejects S1. Thus, exclusive contrast is based on two conditions:

23. For instance, in [30], the inferred condition is <If I badn't needed to talk to you > and S2 is its apodosis, i.e., "I wouldn't have called".

24. This might explain why dacă/de nu can work in [31]: "I hope that we can finally agree. If not/Dacă nu (i.e., if we don't agree), we will have a problem"; but not in [30]: "I need to talk to you. *If not/Dacă nu (i.e., if I don't need), I wouldn't have called so late". 
1. Two different compared items occupy mutually exclusive regions in a shared domain.

2. The compared items are two different tokens of the identical entity before and after removal/relocation (Izutsu, 2008: 671).

For instance, the contrast expressed in John is not American but British is based on the shared domain "nationality" and S2 ("being British") rejects S1 ("being American").

According to the stronger or weaker contrast between the two conjuncts, several exclusive meanings can be distinguished, namely refutation, restriction and contraposition.

\subsection{Refutation markers}

Refutation markers express a "yes-no" relation between contrary poles. The basic refutation marker is Cat. sinó (que), Sp. sino (que), Ro. ci, but there are other refutation markers, as Table 6 shows.

\begin{tabular}{|c|c|c|c|c|}
\hline Spanish & Catalan & Italian & Romanian & \\
\hline $\begin{array}{l}\operatorname{sino}(\mathrm{Cj}) \\
\text { ("if not") }\end{array}$ & $\begin{array}{l}\text { sinó }(\mathrm{Cj}) \\
\text { ("if not”) }\end{array}$ & $\begin{array}{l}\text { ma }(\mathrm{Cj}) \\
\text { (> "more"), } \\
\text { bensì } \\
\text { (“well yes") }\end{array}$ & $\mathbf{c i}(\mathrm{Cj})$ & "exclusive but" \\
\hline $\begin{array}{l}\text { al contrario } \\
\text { (and variants) } \\
\text { ("at/for the } \\
\text { contrary"), } \\
\text { todo lo contrario } \\
\text { ("all the } \\
\text { contrary") }\end{array}$ & $\begin{array}{l}\text { al contrari } \\
\text { (and variants) } \\
\text { ("at/for the } \\
\text { contrary") }\end{array}$ & $\begin{array}{l}\text { al contrario } \\
\text { ("at the } \\
\text { contrary") }\end{array}$ & $\begin{array}{l}\text { dimpotrivă } \\
\text { (> "from } \\
\text { against"), } \\
\text { din contra/din } \\
\text { contră } \\
\text { ("from the } \\
\text { contrary") }\end{array}$ & $\begin{array}{l}\text { "on the } \\
\text { contrary" }\end{array}$ \\
\hline $\begin{array}{l}\text { antes bien } \\
\text { ("before well") }\end{array}$ & $\begin{array}{l}\text { ans bé } \\
\text { ("before well") }\end{array}$ & $\begin{array}{l}\text { anzi } \\
\text { (> "before") }\end{array}$ & & $\begin{array}{l}\text { "on the } \\
\text { contrary" }\end{array}$ \\
\hline
\end{tabular}

Table 6 - Refutation markers

Spanish, Catalan and Romanian have dedicated refutation conjunctions: Sp. sino (que), Cat. sinó (que), Ro. ci. In Italian, the general opposition conjunction ma also expresses this meaning, but in some cases it alternates with bensi.

[33] a. SP: No necesito la habitación grande, sino la pequeña / sino que necesito la pequeña.

b. CAT: No necessito l'habitació gran, sinó la petita / sinó que necessito la petita.

c. IT: Non mi serve la stanza grande, ma/bensi (mi serve) quella piccola.

d. RO: Nu am nevoie de sala mare, $c i$ (am nevoie) de cea mică.

'I do not need the big room, but (I need) the small one.' 
In contrast with Sp. sino and Cat. sinó, which need the general complementizer que "that", when the two segments include a verb, the Romanian $c i$ allows for the repetition of the verb in S2 with no additional changes.

Bensi is a specific refutation marker in Italian, belonging to the formal register; it is thus low in frequency ${ }^{25}$.

There are also a number of parenthetical connectives that can express refutation either preceded by an adversative conjunction or on their own, in this case, both at the sentence level and the text level ${ }^{26}$.

[34] a. SP: Juan no es alto sino que, al contrario, es bajo.

b. CAT: En Joan no és alt sinó que, al contrari, és baix.

c. RO: Ion nu este înalt, ci dimpotrivă/din contra este scund.

d. IT: Giovanni non è alto, (ma) bensilanzi è basso.

'John is not tall but, on the contrary, he is short.'

[35] a. SP: El chiste no hizo que se enfadara. Al contrario, le divirtió.

b. CAT: L'acudit no el va fer enfadar. (Ans) al contrari, el va divertir.

c. IT: Lo scherzo non lo fece arrabbiare. Anzi/Al contrario, lo divertì.

d. RO: Gluma nu 1-a enervat. Dimpotrivă/Din contra/Din contră, 1-a amuzat.

'The joke did not make him angry. On the contrary, it amused him.'

Among the parenthetical connectives expressing refutation, there is a group based on the words contrario/contrari/contrario/contra( $\breve{a})$ "contrary".

[36] a. SP: No le importó que saliera con su amigo; al contrariolantes al contrariol muy al contrario/todo lo contrario, se alegró de que nos gustáramos.

b. CAT: No li va importar que sortís amb el seu amic; (ans) al contrari/tot al contrarilben al contrari, es va alegrar que ens agradéssim.

c. IT: Non le dispiaceva che uscissi con il suo amico, al contrario era contento che ci piacessimo.

d. RO: Nu i-a păsat că mă vedeam cu prietenul lui; (ba) (cbiar) din contra(ă)/ dimpotrivă, a fost mulțumit că ne înțelegeam.

'He didn't care that I dated his friend; on the contrary, he was glad that we liked each other.'

25. While traditional grammars and dictionaries consider bensì as a conjunction (e.g., GDLI; GRADIT; Serianni, 1988: 455), it is considered as an "adverbial connector" by Mazzoleni (2015: 177), as it can combine with the adversative conjunction ma (ma bensi). According to Serianni (1988: 455), the use of bensi to convey correction is a relatively recent phenomenon, its use in the past being that of an adverb meaning "certainly" (> "well yes").

26. As a negative polarity item, the dedicated corrective conjunction - Sp. sino (que), Cat. sinó (que), Ro. cicannot connect independent sentences, for it needs to be under the scope of a syntactic negation. At the text level, only parenthetical connectives, which do not need to be under the negation scope, can indicate correction. 
In Spanish and Catalan, these markers have reinforced variants including intensifiers (todo/tot "all", muy "very", ben "well") or comparative markers based on precedence adverbials (antes/ans "before") (Estellés Arguedas \& Cuenca, 2017).

In Romanian, the couple din contraldin contră includes the preposition din, meaning "out of", and two versions of the preposition/adverb contra. Although less obvious, dimpotrivă is an adverbial that also includes "contrary": it is a compound formed by the prepositions de and $\hat{\imath}(m)$ and the noun potrivă $<$ Sl. prot $\breve{v} \breve{u}$, meaning "contrary" (see DER). Italian al contrario is relatively infrequent, perhaps because of the competition with anzi.

A second group of refutation markers is based on adverbial forms derived from Latin ante ("before", "prior to"), namely, Sp. antes bien, Cat. ans bé, It. anzi, which, in the case of Spanish and Catalan can also reinforce al contrario/contrari (Sp. antes al contrario, Cat. ans al contrari), as already mentioned. From a space-temporal meaning of precedence, these forms developed comparative and contrastive meanings that have been kept in some pluriverbal connectives (see Bazzanella, 2003; Cuenca \& Estellés Arguedas, forthcoming; Estellés Arguedas \& Cuenca, 2017; Cuenca \& Visconti, 2017; Visconti, 2015 and 2018).

[37] a. SP: No son inocentes. Antes bien, son culpables de haberlo permitido.

b. CAT: No són innocents. Ans bé, són culpables d'haver-ho permès.

c. IT: Non sono innocenti. Anzi, sono colpevoli di averlo permesso.

'They are not innocent. Quite the opposite, they are guilty for having allowed it.'

In spite of their shared Latin origin, these markers show differences in both function and distribution. In particular, It. anzi displays greater frequency, mobility and scope variability than its Spanish and Catalan counterparts and has developed more uses, e.g., as a non-paraphrastic reformulation marker (see Cuenca \& Visconti, 2017; Sainz, 2014; Visconti, 2015).

\subsection{Restriction markers}

Restriction is related to rectification: S2 substitutes S1, which is presented as an incorrect or not completely adequate formulation (Portolés, 1998: 143). Restriction markers are shown in Table 7.

\begin{tabular}{|l|l|l|l|l|}
\hline Spanish & Catalan & Italian & Romanian & \\
\hline $\begin{array}{l}\text { más bien } \\
\text { ("more well") }\end{array}$ & $\begin{array}{l}\text { més aviat } \\
\text { ("sooner") }\end{array}$ & $\begin{array}{l}\text { piuttosto } \\
\text { ("sooner"), } \\
\text { anzi } \\
\text { (> "before") }\end{array}$ & $\begin{array}{l}\text { mai degrabă/ } \\
\text { mai curând } \\
\text { ("sooner") }\end{array}$ & "rather" \\
\hline $\begin{array}{l}\text { al menos } \\
\text { ("at least") }\end{array}$ & $\begin{array}{l}\text { almenys } \\
\text { ("at least"), } \\
\text { si més no } \\
\text { ("if more not") }\end{array}$ & $\begin{array}{l}\text { almeno } \\
\text { ("at least") }\end{array}$ & $\begin{array}{l}\text { cel puţin } \\
\text { ("the least") }\end{array}$ & "at least" \\
\hline
\end{tabular}

Table 7 - Restriction markers 
[38] a. SP: No pueden imponer la paz los que utilizan las armas. Son, más bien, los que las sufren los que la reclaman.

b. CAT: No poden imposar la pau els que usen armes. Són, més aviat, els que les pateixen aquells que la reclamen.

c. IT: Non possono imporre la pace quelli che usano le armi. Sono piuttosto quelli che ne soffrono che la reclamano / Anzi, sono quelli che ne soffrono che la reclamano.

d. RO: Cei care folosesc armele nu pot impune pacea. Mai degrabă/mai curând, tocmai cei care suferă din cauza armelor cer pacea.

'Those who use weapons cannot impose peace. Rather, those who suffer from weapons ask for peace.'

[39] a. SP: No lo esperaba. Al menos, no ahora.

b. CAT: No ho esperava. Si més no/Almenys, no ara.

c. IT: Non me lo aspettavo. Almeno, non ora.

d. RO: Nu o aşteptam. Cel puţin, nu acum.

'I did not expect it. At least not now.'

The sources of restriction markers include quantifiers (more, less) that allow the reinterpretation of comparison as contrast. The markers either indicate preference or down-toning in a scale.

\subsection{Contraposition markers}

Contraposition markers indicate that $\mathrm{S} 1$ is to be discarded as not valid with respect to S2, which is argumentatively reinforced by the presence of the marker (Portolés, 1998: 143). Contraposition markers are based on the nouns realitat/realidad/realtàl realitate "reality" and fet/hecho/fapt "fact" or effetti "effects", which present S2 as the reality and then activate the implication that S1 is not "real" (Canes Nápoles \& Delbecque, 2017).

\begin{tabular}{|l|l|l|l|l|}
\hline Spanish & Catalan & Italian & Romanian & \\
\hline $\begin{array}{l}\text { en realidad } \\
\text { ("in reality") }\end{array}$ & $\begin{array}{l}\text { en realitat } \\
\text { ("in reality") }\end{array}$ & $\begin{array}{l}\text { in realtà } \\
\text { ("in reality") }\end{array}$ & $\begin{array}{l}\text { in realitate } \\
\text { ("in reality") }\end{array}$ & $\begin{array}{l}\text { "in reality"/ } \\
\text { "actually" }\end{array}$ \\
\hline $\begin{array}{l}\text { de hecho } \\
\text { ("of fact") }\end{array}$ & $\begin{array}{l}\text { de fet } \\
\text { ("in fact"), } \\
\text { fet i fet } \\
\text { ("fact and fact") }\end{array}$ & $\begin{array}{l}\text { in effetti } \\
\text { ("in effects"), } \\
\text { di fatto } \\
\text { ("of fact") }\end{array}$ & $\begin{array}{l}\text { in/de fapt } \\
\text { ("in/of fact") }\end{array}$ & "in fact" \\
\hline
\end{tabular}

Table 8 - Contraposition markers 
[40] a. SP: Sus acciones parecían cuidadosamente preparadas. En realidad, actuaba aleatoriamente.

b. CAT: Les seves accions semblaven preparades amb cura. En realitat, actuava aleatòriament.

c. IT: Le sue azioni sembravano attentamente pianificate. In realtà, agiva a caso.

d. RO: Acțiunile lui păreau planificate cu grijă. In realitate, acționa la întâmplare.

'His actions seemed carefully planned. In reality, he acted at random.'

[41] a. SP: Nos dijo que su hijo había aprobado el exámen, pero, de hecho, ni siquiera se había presentado.

b. CAT: Ens va dir que el seu fill havia aprovat l'examen, però, de fet, ni tan sols s'hi havia presentat.

c. IT: Ci ha detto che suo figlio aveva passato l'esame, ma, in effetti/di fatto, non l'aveva neanche dato.

d. RO: Ne-a spus că fiul ei a luat examenul. Dar, în/de fapt, nici nu s-a prezentat. 'She told us her son passed the exam. But, in fact, he did not even take it.'

Contraposition markers based on the nouns fet/hecholfattolfapt "fact" are scalar ${ }^{27}$. Indeed, across languages, many of these items developed from non-scalar meanings, and came to invoke scalarity, by signaling linguistically that the proposition over which they have scope is ranked on a higher level on a scale of epistemic commitment or rhetorical strength (Traugott \& Schwenter, 2000).

\section{Conclusions}

Contrastive markers in Romance languages show interesting similarities but also differences and specificities worth analyzing. In this paper, the main contrastive markers in four Romance languages (Spanish, Catalan, Italian and Romanian) have been classified according to their specific meaning and compared taking into account their source. Although these pages cannot include all possible markers and the details needed to account for them exhaustively, we have attempted to provide a general view and taxonomic proposal of contrastive discourse markers cross-linguistically, adopting an onomasiological perspective.

As far as similarities are concerned, Spanish, Catalan, Italian, and Romanian express weak contrast, conditional opposition, restriction, and contraposition by means of markers from common sources, with Romanian iar as the only exception. The four languages under analysis share some structures, which have either common etymons (e.g., Sp. en realidad, Cat. en realitat, It. in realtà, Ro. în realitate) or are based on similar patterns (e.g., the meaning of precedence in time - "sooner" - in Cat. més aviat, It. piuttosto, Ro. mai curând).

27. These markers, except for Ro. în/de fapt, can also be additive, specifically elaborative, in non-contrastive contexts. Ro. in/de fapt has specialized in signaling contraposition; the additive uses corresponding to in fact are covered by a different marker, de altfel/de altminteri. 
Opposition markers also share sources. All languages include markers based on the word for "change/place" or "contrary". However, the general markers differ as for form/source or use. Spanish, Catalan and Italian include perolperò, a development of a causal phrase ("for this"), but the syntactic behavior and meaning of the markers are not the same cross-linguistically. The analysis just sketched here shows how forms with a common origin, such as Sp. pero/Cat. però/It. però, have both converged and diverged: while Spanish and Catalan share this form as the general conjunction for non-exclusive contrast, Italian only occasionally resorts to però as a conjunction, ma being the general contrastive conjunction. Conversely, the outcomes of Lat. magis in Spanish (mas) and Catalan (mes) are no longer used as adversative conjunctions.

Concessive opposition markers are mostly grammaticalized forms having a deictic endophoric origin (including forms for "this" or "so" and "all" or "any" followed by general nouns). The persistence of the discourse deictic value explains their mixed nature between adversativity and concession: the marker introduces S2, as in the adversative scheme, but the deictic represents S1 in S2 and S1 is also highlighted, as in the concessive scheme. The source of pero/però is also endophoric ("for this"). While initial pero/però is a conjunction expressing opposition, non-initial però in Italian and Catalan is used to express opposition-concessive meanings, though the uses of però are not completely the same in the two languages.

Exclusive contrast is typically expressed by a dedicated conjunction in Spanish (sino (que)), Catalan (sinó (que)) and Romanian (ci), whereas only Italian can express both exclusive and non-exclusive contrast with a single unspecified marker, ma "but". Italian also has a dedicated non-exclusive conjunction (bensi), but its use is not as general as that of its counterparts. As for parenthetical markers indicating refutation, all four languages include forms based on a word meaning "contrary" (al contrariol al contrarilal contrario/din contra-din contră), and Spanish, Catalan and Italian have forms derived from Latin adverb ante "before" (Sp. antes bien, Cat. ans bé, ans al contrari, It. anzi). However, their use and frequency differ to a certain extent, It. anzi being the most frequently used and polyfunctional, since it can also express restriction and non-paraphrastic reformulation.

As far as formal etymological criteria are concerned, there is no etymological connection between the main contrastive conjunctions in Romanian (dar, însă, ci, iar) and their counterparts in the other languages studied. The main representative of the Eastern Romance block stands out among other Romance languages by its use of the conjunction iar and two other conjunctions that mark both opposition and counter-expectation relations, i.e., dar and $\hat{\imath} n s a ̆$. If the former is a general contrastive marker, însă seems to be closer to concessive opposition markers. Moreover, unlike dar, which can only be used in an initial position in S2, insă does not have a fixed position in the clause, and may work as a parenthetical as well, just like però in Catalan and Italian. The same mobility within the clause characterizes totusi, a connective at the border between counter-expectation and concession. 
In conclusion, from a cross-linguistic point of view, contrastive markers in Spanish, Catalan, Italian and Romanian have common sources in many cases, but their respective systems of markers are different, especially in the case of Romanian. Moreover, even when sources coincide, differences in use and frequency can often be identified. Catalan exhibits important coincidences with Spanish but also some coincidences with Italian, thus showing a different pace of grammaticalization in the Romance languages considered ${ }^{28}$. The whole picture nicely points to a gradient that can match geographical distribution. The consideration of other Romance languages would add to the description of a system of discourse markers that has seldom been considered as a whole, including both conjunctions and parenthetical markers. Similarly, a diachronic approach would complement the synchronic panoramic sketch drawn here.

Despite the obvious limitations of this research, the great number of markers referred to and exemplified can be considered a contribution per se. Most monographic studies deal with one marker or a reduced group of markers. Moreover, the onomasiological perspective is underrepresented in the literature on discourse markers when compared to the semasiological approach. In fact, it is seldom the case that an extensive list of forms for a single meaning is described (with the exception of some modern grammars) and all the more so from a cross-linguistic perspective. The fact of considering source as a tertium comparationis is, to our knowledge, also innovative and can pave the way to future cross-linguistic research in the case of related languages.

\section{References}

Acín Villa, E. 1993. Aspectos de la adversación en español actual. La Coruña: Universidade da Coruña, Servicio de Publicacions.

Anscombre, J.-C. \& Ducrot, O. 1977. Deux mais en français? Lingua 43: 23-40.

Bazzanella, C. 2003. Dal latino ante all'italiano anzi: la "deriva modale". In A. GarceA (ed.), Colloquia Absentium. Studi sulla comunicazione epistolare in Cicerone. Turin: Rosenberg: 123-140.

BîlbîIE, G. \& Winterstein, G. 2011. Expressing Contrast in Romanian. The Conjunction Iar. In J. Berns, H. Jacobs \& T. Scheer (eds.), Romance Languages and Linguistic Theory 2009. Selected Papers from “Going Romance” Nice 2009. Amsterdam: J. Benjamins: 1-18.

Canes Nápoles, A. \& Delbecque, N. 2017. En realidad, polisemia y polifuncionalidad de un marcador discursivo. Revista internacional de lingüística iberoamericana 29: 173-205.

Cuenca, M.J. 1991. Les oracions adversatives. Barcelona - Valencia: Publicacions de l'Abadia de Montserrat - Institut Interuniversitari de Filologia Valenciana.

28. On this topic, see Lamiroy \& Pineda (2017). Our results seem to locate Catalan between Spanish and Italian as for the development of contrastive markers, which differs from the general cline proposed in Lamiroy and Pineda: French $>$ Catalan $>$ Italian $>$ Spanish. Differences according to phenomena are already reported and expected. The analysis of French would bring light on this hypothesis, too. 
Cuenca, M.J. 1992-1993. Sobre l'evolució dels nexes conjuntius en català. Llengua $i$ Literatura 5: 171-213.

CuencA, M.J. 2001. Los conectores parentéticos como categoría gramatical. Lingüística Española Actual 23 (2): 211-235.

CuEnCA, M.J. 2002. Els connectors textuals i les interjeccions. In J. SolÀ, M.-R. Lloret, J. Mascaró \& M. Pérez Saldanya (eds.), Gramàtica del català contemporani. Barcelona: Empúries. Vol. 3: 3173-3237.

Cuenca, M.J. 2006. La connexió i els connectors. Perspectiva oracional i textual. Vic: Eumo.

Cuenca, M.J. 2013. The Fuzzy Boundaries between Discourse Marking and Modal Marking. In L. Degand, B. Cornillie \& P. Pietrandrea (eds.), Discourse Markers and Modal Particles: Categorization and Description. Amsterdam - Philadelphia: J. Benjamins: 191-216.

CuEncA, M.J. \& Estellés ArguedAs, M. forthcoming. Los marcadores contrastivos antes bien, antes al contrario y al contrario en español actual. In C. FuENTEs Rodríguez, A. Messias Nogueira da Silva \& M. Martí Sánchez (eds.), Aportaciones desde el español y el portugués a los marcadores discursivos (Treinta años después de Martín Zorraquino y Portolés). Seville: Publicaciones de la Universidad de Sevilla: 169-187.

Cuenca, M.J. \& Visconti, J. 2017. De la precedencia temporal al contraste: el marcador del discurso ans en catalán y anzi en italiano. Pragmalingüística, Monográfico 1: 89-107.

Diк, S.C. 1968. Coordination. Its Implications for the Theory of General Linguistics. Amsterdam: North-Holland Publishing Company.

Ducrot, O. 1984. Le dire et le dit. Paris: Minuit.

Ducrot, O. \& Vogt, C. 1979. De magis à mais: une hypothèse sémantique. Revue de linguistique romane 43 (171-172): 317-341.

Estellés Arguedas, M. \& CuencA, M.J. 2017. Ans y antes: de la anterioridad a la refutación en catalán y en español. Zeitschrift für Katalanistik 30: 165-184. Available online: http:// www.romanistik.uni-freiburg.de/pusch/zfk/30/11_Estelles_Cuenca.pdf.

Foolen, A. 1991. Polyfunctionality and the Semantics of Adversative Conjunctions. Multilingua 10 (1-2): 79-92.

Fuentes Rodríguez, C. 1998. Las construcciones adversativas. Madrid: Arco Libros.

Fuentes Rodríguez, C. 2009. Diccionario de conectores y operadores del español. Madrid: Arco Libros.

Garachana, M. 2019. Més enllà de la gramaticalització. El desenvolupament del marcador discursiu no obstant això en català. Caplletra 66: 137-162.

Giacalone Ramat, A. \& Mauri, C. 2008. From Cause to Contrast: A Study in Semantic Change. In E. Verhoeven, S. Skopeteas, Y.-M. Shin, Y. Nishina \& J. Helmbrecht (eds.), Studies on Grammaticalization. Berlin - New York: De Gruyter: 303-321.

Giacalone Ramat, A. \& Mauri, C. 2012. The Development of Adversative Connectives: Stages and Factors at Play. Linguistics 50 (2): 191-239.

Izutsu, M.N. 2008. Contrast, Concessive, and Corrective: Toward a Comprehensive Study of Opposition Relations. Journal of Pragmatics 40 (4): 646-675.

Lamiroy, B. \& Charolles, M. 2005. Utilisation de corpus pour l'évaluation d'hypothèses linguistiques. Le cas de autrement. In A. Condamines (ed.), Sémantique et corpus. Paris: Lavoisier: 109-147. 
LAmiroy, B. \& PinEDA, A. 2017. Grammaticalization across Romance Languages and the Pace of Language Change. The Position of Catalan. Lingvistice Investigationes 40 (2): 304-331.

LANG, E. 2000. Adversative Connectors on Distinct Levels of Discourse: A Re-examination of Eve Sweetser's Three-Level Approach. In E. Couper-Kunlen \& B. Kortmann (eds.), Cause-Condition-Concession-Contrast. Cognitive and Discourse Perspectives. Berlin New York: De Gruyter: 235-256.

Lopes, A.C.M. \& SousA, S. 2014. The Discourse Connectives ao invés and pelo contrário in Contemporary European Portuguese. Journal of Portuguese Linguistics 13 (1): 3-27.

Marconi, D. \& Bertinetto, P.M. 1984. Ma in italiano. Parte prima: semantica e pragmatica. Lingua e Stile 19: 223-258.

Martín Zorraquino, M.A. \& Portolés LÁzaro, J. 1999. Los marcadores del discurso. In I. Bosque \& V. Demonte (eds.), Gramática descriptiva de la lengua española. Madrid: Espasa-Calpe. Vol. 3: Entre la oración y el discurso. Morfología: 4051-4213.

Mauri, C. 2008. Coordination Relations in the Languages of Europe and Beyond. Berlin New York: De Gruyter.

Mazzoleni, M. 2000. Costrutti concessivi e costrutti avversativi in alcune lingue d'Europa. Pavia: La Nuova Italia.

Mazzoleni, M. 2015. Connettori, grammatica e testi: ma e (ben)si tra costrutti avversativi, sostitutivi e preconcessivi. In A. Ferrari, L. Lala, R. Stojmenova (eds.), Testualità. Fondamenti, unità, relazioni. Florence: Franco Cesati Editore: 171-188.

Muñoz Garrigós, J. 1981. Sobre el origen de los nexos adversativos en español. Cabiers de linguistique bispanique médiévale 6: 41-56.

Niculescu, A. 1965. Observaţii asupra conjuncţiilor adversative în limbile romanice. Conjuncţia adversativ-copulativă. In A. Niculescu (ed.), Individualitatea limbii române intre limbile romanice. Contribuții gramaticale. Bucharest: Editura Ştiinţifică.

Portolés, J. 1998. Marcadores del discurso. Barcelona: Ariel.

Postolea, S. 2018. Using Annotation to Identify Connective Meanings in a Multilingual Environment. Romanian and English Contrast Markers in a Parallel Corpus. In L.-M. HoDAC \& P. Muller (eds.), Cross-linguistic Discourse Annotation: Applications and Perspectives. Toulouse: Université Paul Sabatier - Toulouse 3: 107-113. Available online: http:// textlink.ii.metu.edu.tr/sites/default/files/textlink_proceedings.pdf\#page=116.

Proietti, D. 2015. Ancora sulla diacronia di però. Cuadernos de Filología Italiana 22: 73-104.

SAINZ, E. 2014. El reformulador italiano anzi y sus formas equivalentes en español. In E. SAInz (ed.), De la estructura de la frase al tejido del discurso. Estudios contrastivos español/italiano. Bern: P. Lang: 141-175.

SAInZ, E. 2015. Al contrario (esp.) / al contrario (it.); en cambio (esp.) / invece (it.): codificación semántica y funcionamiento discursivo. In M. Borreguero Zuloaga \& S. GómezJORDANA FERARY (eds.), Les marqueurs du discours dans les langues romanes: une approche contrastive. Limoges: Lambert-Lucas: 95-113.

Sanders, T.J.M., Demberg, V., Hoek, J., Scholman, M.C.J., Asr, F.T., Zufferey, S. \& Evers-Vermeul, J. 2018. Unifying Dimensions in Coherence Relations: How Various Annotation Frameworks Are Related. Corpus Linguistics and Linguistic Theory (Ahead of print): $1-71$. 
Santos Río, L. 2003. Diccionario de partículas. Salamanca: Luso-Española de Ediciones.

Scorretti, M. 1988. Le strutture coordinate. In L. ReNZI (ed.), Grande grammatica italiana di consultazione. Bologna: Il Mulino. Vol. 1: La frase, i sintagmi nominale e preposizionale: $227-270$.

SERIANnI, L. 1988. Grammatica italiana. Italiano comune e lingua letteraria. Suoni, forme, costrutti. Turin: UTET.

ŞTEFăNESCU, A. 2007. Conectori pragmatici. Bucharest: Editura Universităţii din Bucureşti.

Ștefănescu, A. \& Postolea, S. 2018. The Attitudinal Meaning of altfel/altminteri ("otherwise") as Textual Connectors and Discourse Markers. In The 18th International Conference of the Department of Linguistics: "Romanian and the Romance Languages" (University of Bucharest, 23-24 November 2018).

SweEtser, E. 1990. From Etymology to Pragmatics. Metaphorical and Cultural Aspects of Semantic Structure. Cambridge - New York - Melbourne: Cambridge University Press.

Traugott, E.C. \& Schwenter, S. 2000. Invoking Scalarity: The Development of in fact. Journal of Historical Pragmatics 1 (1): 7-25.

Vasilescu, A. 2010. Iar - Operator Pragmatic. In R. Zafiu, A. Dragomirescu \& A. Nicolae (eds.), Limba română: controverse, delimitări, noi ipoteze. Actele celui de-al nouălea Colocviu al Catedrei de Limba Română. Bucharest: Editura Universităţii din Bucureşti: 341-355.

VIsConti, J. 2015. La diacronia di anzi: considerazioni teoriche, dati e prime ipotesi. Cuadernos de Filología Italiana 22: 105-116.

Visconti, J. 2018. On the Origins of Italian anzi. In D. VAN Olmen, T. Mortelmans \& F. BrISARD (eds.), Aspects of Linguistic Variation. Berlin - New York: De Gruyter: 269-278.

ZAFIU, R. 2005. Conjuncţiile adversative în limba română: tipologie şi niveluri de incidenţă. In G. Pană Dindelegan (ed.), Limba română - structură şi funcţionare. Bucharest: Editura Universităţii din Bucureşti: 243-258.

\section{Dictionaries}

DER - CioRăNescu, A. 1958-1966. Dicționarul etimologic român. Tenerife: Universidad de la Laguna.

DPDE - Briz, A., Pons, S. \& Portolés, J. (eds.) 2008. Diccionario de partículas discursivas del español. Available online: http://www.dpde.es.

DULR - ȘăINEANU, L. 1929. Dicționar universal al limbei române. Craiova: Editura „Scrisul românesc" S.A. [6th ed.].

GALR I - Guțu-Romalo, V. \& Institutul de Lingvistică „Iorgu Iordan - Alexandru Rosettr" (éd.) 2005. Gramatica limbii române. Bucharest: Editura Academiei Române. Vol. I: Cuvântul.

GALR II - Guțu-Romalo, V. \& Institutul De Lingvistică „Iorgu Iordan - Alexandru Rosettr" (éd.) 2005. Gramatica limbii române. Bucharest: Editura Academiei Române. Vol. II: Enunţul.

GDLI - Battaglia, S. 1961-2008. Grande dizionario della lingua italiana. Turin: UTET. $24 \mathrm{vol}$

GRADIT - De Mauro, T. 1999-2000. Grande dizionario italiano dell'uso. Turin: UTET. 6 vol. 